\title{
Anaerobic degradation of pimelate by newly isolated denitrifying bacteria
}

\author{
Corinna Gallus and Bernhard Schink
}

Author for correspondence: Corinna Gallus. Tel: +497531 882973. Fax: + 497531882966 .

Fakultät für Biologie, Universităt Konstanz, Postfach 5560, 78434 Konstanz, Federal Republic of Germany
A $C_{7}$ dicarboxylic (pimelic) acid derivative is postulated as an intermediate in anaerobic degradation of benzoate. Four strains of Gram-negative, nitratereducing bacteria capable of growth with both pimelate and benzoate as sole carbon and energy source were isolated. The metabolism of strain LP-1, which was enriched from activated sludge with pimelate as substrate, was studied in detail. This strain grew only with oxygen or with oxidized nitrogen compounds as electron acceptor. In the presence of nitrate, a wide range of substrates excluding $C_{1}$ compounds was degraded. The new isolate was catalase- and oxidase-positive, and had one single polar flagellum. Strain LP-1 was tentatively classified within the family Pseudomonadaceae. The catabolism of pimelate and benzoate was studied in cell-free extracts of strain LP-1. Both acids were activated with coenzyme $A$ in $\mathbf{a} \mathbf{M g}^{2+}$ and ATP-dependent reaction. The corresponding acyl-CoA synthetases were specifically induced by the respective growth substrate. Pimelate was also activated by $C O A$ transfer from succinyl-CoA. Pimelyl-CoA was oxidized by cell-free extracts in the presence of potassium ferricyanide. Degradation to glutaryl-CoA and acetyl-CoA proceeded by a sequence of $\beta$-oxidation-like reactions. Glutaryl-CoA dehydrogenase and glutaconyl-CoA decarboxylase activities were expressed in cells grown with pimelate or benzoate, indicating the specific involvement of these enzyme activities in anaerobic degradation of these two acids. Enzyme activities responsible for further degradation of the resulting crotonyl-CoA to acetylCoA via classical $\beta$-oxidation were also detected.

Keywords: denitrifying bacteria, anaerobic metabolism, benzoate degradation, pimelate degradation, glutaconyl-CoA

\section{INTRODUCTION}

Derivatives of heptanedioic (trivial name: pimelic) acid are involved in biosynthetic reactions such as the microbial synthesis of biotin (Eisenberg \& Star, 1968) and lysine (Gottschalk, 1986). Also in several degradative pathways pimelic acid acts as an intermediate. Aerobic degradation of cycloheptane and cycloheptanol proceeds via pimelate (Hasegawa et al., 1982). A pimelic acid derivative is also postulated as an intermediate in anaerobic degradation of benzoyl-CoA (Dutton \& Evans, 1968; Guyer \& Hegeman, 1969), the central intermediate in anaerobic metabolism of many aromatic compounds such as phenol (Tschech \& Fuchs, 1987), p-cresol (Rudolphi et al., 1991), aniline and 4-aminobenzoate (Schnell \& Schink, 1991). Pimelyl-mono-CoA (Schink et al., 1992), pimelyl-di-CoA (Evans \& Fuchs, 1988) or 3-hydroxypimelyl-CoA (Koch et al., 1993) have been postulated to be the primary ring cleavage product.
The pathway of pimelate degradation has not been studied so far. Presumably, the acid is first activated, yielding pimelyl-mono-CoA. Pimelyl-CoA is expected to be degraded via glutaryl-CoA to three acetyl-CoA residues plus one $\mathrm{CO}_{2}$ (Blakley, 1978). In the present study, the anaerobic degradation of pimelate was investigated taking into account that this pathway might be linked to that of anaerobic benzoate degradation by a common intermediate. To allow a comparison of both pathways, we enriched for denitrifying bacteria and isolated those which were able to grow with pimelate as well as with benzoate as sole carbon and energy source. One strain, LP-1, was characterized in more detail to investigate the catabolism of these acids.

\section{METHODS}

Sources of organisms. Bacteria were enriched from activated sludge of the municipal sewage plant in Tübingen-Lustnau, 
FRG, and from surface sediments of a pond in the botanical garden in Tübingen, FRG.

Media and growth conditions. For enrichment and anaerobic cultivation, a bicarbonate-buffered mineral salts medium was prepared as described by Widdel \& Pfennig (1981). The medium contained $1 \mathrm{mM} \mathrm{Na}_{2} \mathrm{SO}_{4}$ as sulphur source, and no sulphide. $\mathrm{NaHCO}_{3}(30 \mathrm{mM}$ ), trace element solution SL 10 (Widdel et al., 1983), selenite/tungstate solution (Tschech \& Pfennig, 1984), and vitamin solution (Pfennig, 1978) were added after sterilization. Substrates and electron acceptors were added from sterile stock solutions. Cultures were incubated at $30{ }^{\circ} \mathrm{C}$ in test tubes or infusion bottles sealed with butyl rubber septa under a $\mathrm{N}_{2} / \mathrm{CO}_{2}(90: 10 ; \mathrm{v} / \mathrm{v})$ atmosphere. For aerobic cultivation, a phosphate-buffered mineral medium (Weimer \& Zeikus, 1977) was used, supplemented with vitamins and trace elements as described above. The cultures were incubated in Erlenmeyer flasks on a rotary shaker (100 r.p.m.) at $30^{\circ} \mathrm{C}$. Growth was followed by measuring the optical density at $578 \mathrm{~nm}$ either in a Hitachi 100-40 spectrophotometer (Tokyo, Japan) or in a Spectronic-20 photometer (Bausch \& Lomb). Substrate utilization was determined by high-performance liquid chromatography (HPLC) as described below.

Isolation and characterization. Pure cultures were obtained by repeated application of the agar shake dilution method (Pfennig, 1978). Purity was checked microscopically and by cultivation in a complex medium diluted 1:10 (AC-medium, Difco). The Gram-type was determined as described by Bartholomew (1962) and Gregersen (1978). Flagellar staining was performed according to Blenden \& Goldberg (1965). Oxidase and catalase tests and the identification of poly- $\beta$-hydroxybutyrate (PHB) were carried out following standard methods (Gerhardt, 1984). Autotrophic growth was tested in infusion bottles which were one-third-filled with medium under a $\mathrm{H}_{2} / \mathrm{CO}_{2}(80: 20$, v/v) atmosphere. Cytochromes were assayed in the soluble protein fraction and in the membrane fraction obtained by ultracentrifugation ( $45 \mathrm{~min}$ at $150000 \mathrm{~g}$ ) of the crude extract. Redox difference spectra (dithionite-reduced minus air-oxidized) were recorded with an Uvicon 860 spectrophotometer (Kontron). The DNA base ratio was determined by HPLC (Tamaoka \& Komagata, 1984; Mesbah et al., 1989). The DNA was isolated according to Cashion et al. (1977). Cells were examined for fluorescent pigments under ultraviolet light at $254 \mathrm{~nm}$ wavelength.

Enzyme assays. Cells were harvested under anoxic conditions in the late exponential growth phase by centrifugation for $30 \mathrm{~min}$ at $9000 \mathrm{~g}$ in a Sorvall RC-2B centrifuge. The pellet was washed in $\mathrm{N}_{2}$-sparged potassium phosphate buffer $(100 \mathrm{mM}$, $\mathrm{pH} 7 \cdot 2)$ or in Tris/HCl buffer $(100 \mathrm{mM}, \mathrm{pH} 8 \cdot 0)$ and resuspended in the same buffer. Cell-free extracts were prepared as described previously (Brune \& Schink, 1990).

All photometric assays were performed using a Hitachi 100-40 spectrophotometer. Enzymes of fatty acid $\beta$-oxidation were measured by standard methods (Bergmeyer, 1983). For determination of glutaryl-CoA dehydrogenase activity, an assay for succinate dehydrogenase (Stams et al., 1984) was slightly modified. The reaction mixture contained potassium phosphate buffer $(50 \mathrm{mM}, \mathrm{pH} 7 \cdot 2), 1 \cdot 0 \mathrm{mM} \mathrm{K}_{3}\left[\mathrm{Fe}(\mathrm{CN})_{6}\right], 0 \cdot 1 \mathrm{mM}$ phenazine methosulphate, and $0.5 \mathrm{mM}$ glutaryl-CoA. GlutaconylCoA decarboxylase was measured in a coupled assay using a mixture of five auxiliary enzymes isolated from Acidaminococcus fermentans (Buckel, 1986). The assay mixture contained potassium phosphate buffer $(50 \mathrm{mM}, \mathrm{pH} 7 \cdot 2)$, Triton $\mathrm{X}-100(1 \%$, $\mathrm{w} / \mathrm{v}), 20 \mathrm{mM} \mathrm{NaCl}, 2 \mathrm{mM}$ DTE, $2 \mathrm{mM}$ EDTA, $1 \mathrm{mM} \mathrm{NAD}{ }^{+}$, $1 \mathrm{mM}$ acetylphosphate, $0 \cdot 125 \mathrm{mM} \mathrm{CoASH}$, auxiliary enzymes $\left(0 \cdot 2 \mathrm{mg}\right.$ protein $\left.\mathrm{ml}^{-1}\right)$, and $1 \mathrm{mM}$ sodium glutaconate. AcetylCoA synthetase assays were performed discontinuously following CoA ester formation by HPLC (Schnell \& Schink, 1991). Acyl-CoA transferases were measured in the same way except that free coenzyme A was substituted by the prospective thioester as CoA donor, and ATP was omitted from the reaction mixture. The enzyme activities catalysing the reactions leading from glutaryl-CoA to acetyl-CoA were also demonstrated in an assay in which all steps of the whole sequence were coupled. The reaction mixture contained Tris/ $\mathrm{HCl}$ buffer $(100 \mathrm{mM}, \mathrm{pH} 8.0)$, $10 \mathrm{mM} \mathrm{MgCl}_{2}, 1.0 \mathrm{mM} \mathrm{K}_{3}\left[\mathrm{Fe}(\mathrm{CN})_{6}\right]$, and, if appropriate, $0.5 \mathrm{mM} \mathrm{NAD}^{+}$. The reaction was started by addition of $1.0 \mathrm{mM}$ glutaryl-CoA. Samples were taken with gas-tight microlitre syringes (Unimetrics, Macherey \& Nagel) and analysed by HPLC. The same procedure was used to measure pimelyl-CoA degradation except that the reaction was initiated with pimelylCoA instead of glutaryl-CoA. In some assays cell-free extracts were used which were preincubated with iodoacetamide $\left[0 \cdot 14 \mu \mathrm{mol}(\mathrm{mg} \text { protein })^{-1}\right]$ for $15 \mathrm{~min}$ at room temperature to inhibit $\beta$-ketothiolase activity (Lynen \& Ochoa, 1953).

Chemical analyses. Aromatic compounds and thioesters were identified and quantified by reversed phase chromatography with peak detection at $230 \mathrm{~nm}$ and $260 \mathrm{~nm}$ (Brune \& Schink, 1990). For quantification of pimelate, an Interaction ORH-801 organic acids column $(300 \times 6.5 \mathrm{~mm})$ packed with a cationexchange polymer (Interaction Chemicals) was used, eluting isocratically with $5 \mathrm{mM}$ sulphuric acid. Peaks were detected by a refraction index detector ERC-7512 (Sykam). Pimelyl-CoA was identified and quantified after alkaline hydrolysis by measuring the concentration of the resulting pimelate and CoA. Nitrate (Lange \& Vejdelek, 1980), nitrite (Procházková, 1959), and ammonia (Chaney \& Marbach, 1962) were quantified by previously described procedures. Protein was determined by the biuret method (Cooper, 1981) with bovine serum albumin as standard.

To identify 3-oxoacyl-CoA, the $\mathrm{pH}$ of a sample purified by HPLC was adjusted to $\mathrm{pH} 9 \cdot 0$ with $1 \mathrm{M} \mathrm{NaOH}$. After addition of $\mathrm{MgCl}_{2}$, the UV spectrum was recorded against an appropriate blank in a double-beam spectrophotometer. A specific absorption maximum at $303 \mathrm{~nm}$ is caused by the chelation of $\mathrm{Mg}^{2+}$ ions with the enoyl-form of 3-oxoacyl-CoA which is favoured by the alkaline $\mathrm{pH}$, as observed with acetoacetyl-CoA (Stern, 1956).

Chemicals. Pimelyl-CoA was chemically synthesized by a procedure modified after Simon \& Shemin (1953). Ethylchloroformate $(88 \mu \mathrm{l})$ and triethylamine $(120 \mu \mathrm{l})$ were added to $880 \mu \mathrm{mol}$ pimelic acid dissolved in $40 \mathrm{ml}$ dry tetrahydrofuran under a nitrogen atmosphere. After incubation at room temperature for $3 \mathrm{~h}$, the triethylammonium chloride precipitate was removed by filtration in an anaerobic chamber (Coy Laboratory Products). A $4 \mathrm{ml}$ portion of this filtrate was continuously added over a $3 \mathrm{~h}$ period to $8 \mathrm{ml}$ of a $5 \mathrm{mM} \mathrm{CoA}$ solution under anoxic conditions. The $\mathrm{pH}$ of the reaction mixture was maintained at $7 \cdot 0-8 \cdot 0$ by addition of $0.1 \mathrm{M} \mathrm{NaOH}$, and the reaction was followed by HPLC. After disappearance of free CoA, the solution was frozen in liquid nitrogen and concentrated by lyophilization. Pimelyl-CoA was purified by HPLC using a semipreparative reverse-phase ultrasphere column $(5 \mu \mathrm{m}, 10 \times 250 \mathrm{~mm}$; Beckman Instruments $)$ at a flow rate of $3 \mathrm{ml} \mathrm{min}^{-1}$ with methanol and aqueous ammonium acetate solution $(100 \mathrm{mM}, \mathrm{pH} 3.0)$. The gradient used started with $10 \%(\mathrm{v} / \mathrm{v})$ methanol. After $1 \mathrm{~min}$, the concentration of methanol was linearly increased to $70 \%$ over $10 \mathrm{~min}$. At $14 \mathrm{~min}$ after injection, the column was equilibrated with $10 \%$ methanol. The purified pimelyl-CoA was lyophilized again and resus- 
pended in a few microlitres of potassium phosphate buffer (100 mM, pH 6.0).

All other chemicals used were obtained from Aldrich, Boehringer Mannheim, Fluka, Merck and Sigma. All chemicals were of p.a. quality. Gases were obtained from Messer Griesheim.

\section{RESULTS}

\section{Enrichment and isolation}

Enrichment cultures in anoxic mineral medium containing $10 \mathrm{mM}$ sodium nitrate as electron acceptor and either $2.5 \mathrm{mM}$ pimelate or $2.5 \mathrm{mM}$ benzoate as sole organic carbon source were inoculated with $10 \%(\mathrm{v} / \mathrm{v})$ inoculum from activated sludge or from surface sediments (upper $5 \mathrm{~cm}$ ). After $4 \mathrm{~d}$ incubation, microbial growth was indicated by gas production (probably $\mathrm{N}_{2}$ ), increased turbidity, and a decrease in substrate concentration. After several transfers, all enrichment cultures with benzoate were transferred to medium containing pimelate, and vice versa. From these subcultures four strains of denitrifying bacteria were isolated by two subsequent agar dilution series.

All four new isolates were Gram-negative. Cells varied from cocci to coccoid short rods. Cells of the two strains originally enriched with benzoate were nonmotile, whereas cells of the other two strains were rod-shaped and

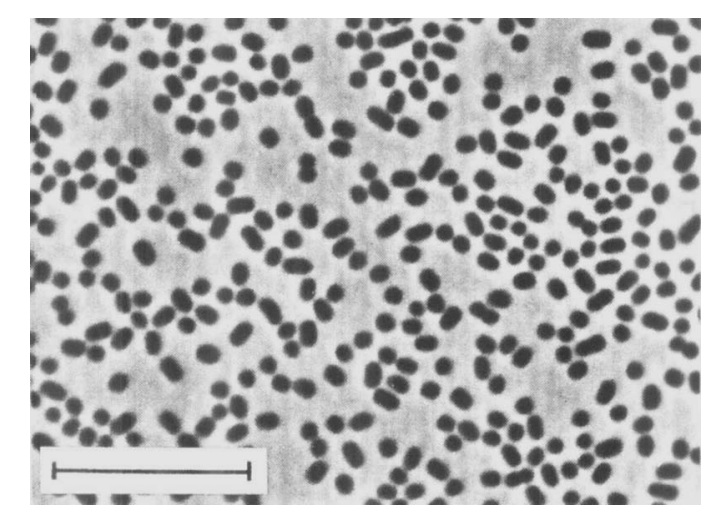

Fig. 1. Phase-contrast photomicrograph of strain LP-1 cells. Bar, $10 \mu \mathrm{m}$. motile by polar flagellation. As the four strains appeared to be physiologically very similar, one strain was selected to study the catabolism of pimelate and benzoate. Strain LP-1 (Fig. 1), isolated from activated sludge with pimelate as initial substrate, was the isolate with the shortest doubling time and was therefore used for further investigations.

\section{Morphological and cytological characterization of strain LP-1}

Cells of strain LP-1 were short Gram-negative rods, $1 \cdot 0-2 \cdot 0 \times 0 \cdot 8 \mu \mathrm{m}$ in size, and were motile by one single polar flagellum. Light-refractile inclusions observed by phase-contrast microscopy were identified by chemical analysis as poly- $\beta$-hydroxybutyrate. Redox difference spectra revealed absorption bands at $551 \mathrm{~nm}, 521 \mathrm{~nm}$ and $419 \mathrm{~nm}$ in the soluble protein fraction, and at $556 \mathrm{~nm}$, $538 \mathrm{~nm}$ and $425 \mathrm{~nm}$ in the membrane fraction, indicating the presence of soluble $c$-type and membrane-bound $b$ type cytochromes, respectively (Kamen \& Horio, 1970). Cells of strain LP-1 did not fluoresce under UV-light excitation at $254 \mathrm{~nm}$. The guanine-plus-cytosine content of the DNA was $65 \cdot 54 \pm 0 \cdot 11 \mathrm{~mol} \%$.

\section{Physiological characterization of strain LP-1}

Strain LP-1 grew at temperatures between $4{ }^{\circ} \mathrm{C}$ and $41{ }^{\circ} \mathrm{C}$ and within a $\mathrm{pH}$ range of $6 \cdot 2-8 \cdot 5$. Growth was optimal at $37^{\circ} \mathrm{C}$ and $\mathrm{pH} 7 \cdot 1-7 \cdot 6$. The metabolism was strictly oxidative. No fermentative growth was detected. In the absence of molecular oxygen, only nitrate, nitrite or nitrous oxide served as electron acceptors. Fumarate, sulphate, ferric hydroxide or potassium ferricyanide were not reduced. In the presence of nitrate, many mono- and dicarboxylic acids and some sugars and alcohols were degraded (Table 1). No growth occurred with any of the $\mathrm{C}_{1}$ compounds tested. In addition to benzoate, the only aromatic compounds degraded were 3-hydroxybenzoate, 4-hydroxybenzoate and protocatechuate. No growth was observed with any other hydroxylated benzoate derivative or phenolic compound tested. Chemolithoautotrophic growth with $\mathrm{CO}_{2}$ as sole carbon source and molecular $\mathrm{H}_{2}$ as electron donor was not observed. Cells of strain LP-1 were oxidase- and catalase-positive. Typical growth curves with either pimelate or benzoate and a limiting amount of nitrate are shown in Fig. 2. Nitrate was first

Table 1. Substrates tested for support of anaerobic growth by strain LP-1 in the presence of $5 \mathrm{mM} \mathrm{NaNO}_{3}$

Aromatic compounds were added to $1 \mathrm{mM}$, non-aromatic compounds to $5 \mathrm{mM}$ final concentration.

\begin{tabular}{|c|c|}
\hline Substrates degraded & Substrates not degraded \\
\hline $\begin{array}{l}\text { Propionate, butyrate, isobutyrate, valerate, glutarate, glutaconate, } \\
\text { succinate, adipate, pimelate, } \mathrm{L}(-) \text {-lactate, ethanol, glycerol, } \\
\mathrm{D}(-) \text {-fructose, } \mathrm{D}(+) \text {-glucose }\end{array}$ & Formate, methanol, $\mathrm{L}(+)$-arabinose, $\mathrm{D}(+)$-xylose, $\mathrm{D}(-)$-ribose \\
\hline $\begin{array}{l}\text { Benzoate, 3-hydroxybenzoate, 4-hydroxybenzoate, 3,4- } \\
\text { dihydroxybenzoate }\end{array}$ & $\begin{array}{l}\text { Catechol, resorcinol, 2-hydroxybenzoate, 2,5-dihydroxybenzoate, } \\
\text { 3,5-dihydroxybenzoate, phenol, hydroquinone }\end{array}$ \\
\hline
\end{tabular}



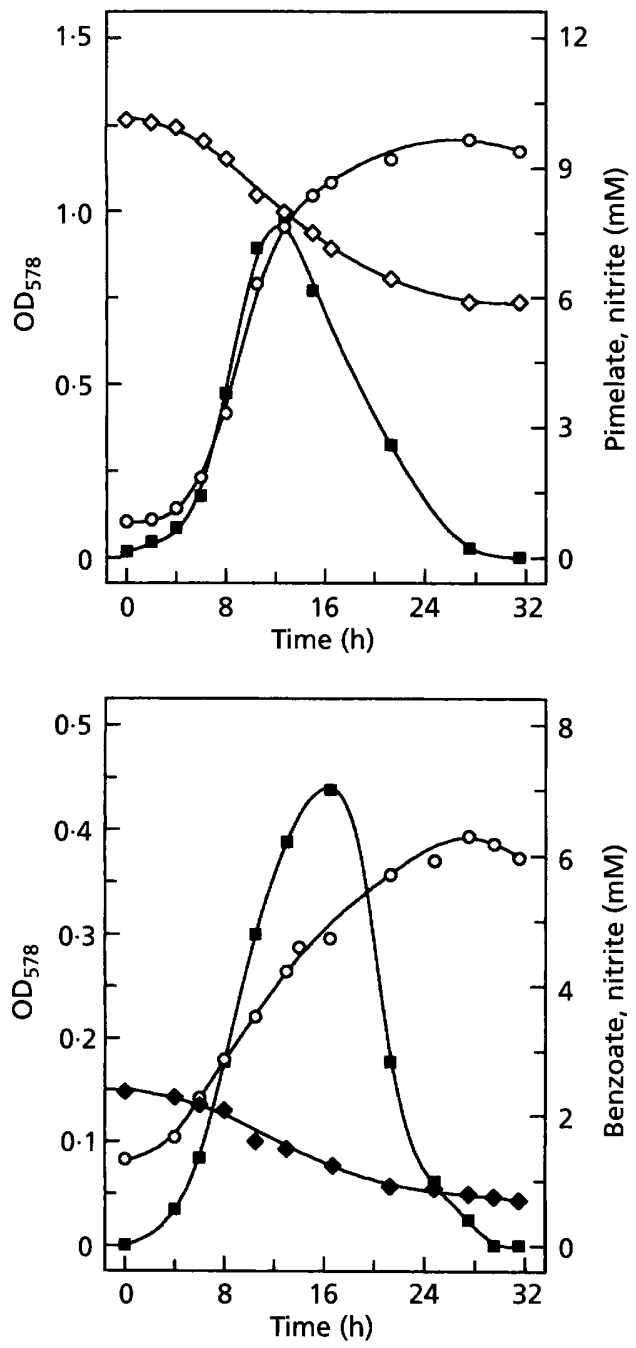

Fig. 2. Growth of strain LP-1 with (a) $10 \mathrm{mM}$ pimelate and $10 \mathrm{mM}$ nitrate, (b) $3 \mathrm{mM}$ benzoate and $8 \mathrm{mM}$ nitrate. $\diamond$, Pimelate; $\diamond$, benzoate; $\mathrm{O}, \mathrm{OD}_{578} ; \mathbf{a}$, nitrite.

reduced to nitrite before $\mathrm{N}_{2}$ was produced. Ammonia was not released. The doubling time at $30{ }^{\circ} \mathrm{C}$ with pimelate was $2.5 \mathrm{~h} \quad\left(\mu=0.28 \mathrm{~h}^{-1}\right)$, and with benzoate $9.0 \mathrm{~h}$ $\left(\mu=0.08 \mathrm{~h}^{-1}\right)$. Growth yields and stoichiometries of pimelate and benzoate degradation by strain LP-1 are given in Table 2 . It was assumed that nitrate was reduced completely to $\mathrm{N}_{2}$.

\section{Activation of pimelate and benzoate}

Pimelate and benzoate were activated with free $\mathrm{CoA}$ in the presence of ATP and $\mathrm{Mg}^{2+}$ by crude extract of cells grown with the corresponding substrate. In this reaction, AMP rather than ADP was formed. Only the respective growth substrate was activated (Table 3 ). The kinetics of pimelyl-CoA and benzoyl-CoA synthetase reactions are presented in Fig. 3. In both cases, also a small amount of acetyl-CoA was produced. Pimelyl-CoA was also synthesized from succinyl-CoA by a CoA-transferase reaction
Table 2. Molar growth yields $\left(Y_{s}\right)$ and stoichiometries of pimelate and benzoate degradation by strain LP-1 with $\mathrm{NaNO}_{3}$ as electron acceptor

\begin{tabular}{|lcc|}
\hline \multicolumn{1}{|c|}{ Substrate... } & Pimelate & Benzoate \\
\hline Substrate consumed $(\mathrm{mmol})$ & $4 \cdot 24$ & $1 \cdot 67$ \\
Cell material formed $(\mathrm{mg})$ & $231 \cdot 2$ & $96 \cdot 2$ \\
Substrate assimilated $(\mathrm{mmol})$ & $1 \cdot 60$ & $0 \cdot 67$ \\
Substrate dissimilated $(\mathrm{mmol})$ & $2 \cdot 64$ & $1 \cdot 00$ \\
Nitrate consumed $(\mathrm{mmol})$ & $17 \cdot 9$ & $7 \cdot 32$ \\
Molar growth yield $\left(Y_{\mathrm{s}}\right)\left(\mathrm{g} \mathrm{mol}^{-\mathbf{1}}\right)$ & $87 \cdot 7$ & $96 \cdot 0$ \\
Electron recovery $(\%)$ & 92 & 107 \\
\hline
\end{tabular}

Substrate consumed in energy metabolism was calculated after equations (1) and (3); substrate assimilated into cell matter was calculated after equations (2) and (4). $\left\langle\mathrm{C}_{4} \mathrm{H}_{7} \mathrm{O}_{3}\right\rangle$ was used as an equivalent of cell matter (Widdel \& Pfennig, 1981). The molar growth yield refers only to the amount of dissimilated substrate.

$$
\begin{aligned}
& \mathrm{C}_{7} \mathrm{H}_{10} \mathrm{O}_{4}^{2-}+6 \cdot 4 \mathrm{NO}_{3}^{-}+8 \cdot 4 \mathrm{H}^{+} \rightarrow 7 \mathrm{CO}_{2}+3 \cdot 2 \mathrm{~N}_{2}+9 \cdot 2 \mathrm{H}_{2} \mathrm{O} \\
& 5 \mathrm{C}_{7} \mathrm{H}_{10} \mathrm{O}_{4}^{2-}+8 \cdot 2 \mathrm{NO}_{3}^{-}+18 \cdot 2 \mathrm{H}^{+} \rightarrow 7\left\langle\mathrm{C}_{4} \mathrm{H}_{7} \mathrm{O}_{3}\right\rangle+7 \mathrm{CO}_{2}+4 \cdot 1 \mathrm{~N}_{2}+9 \cdot 6 \mathrm{H}_{2} \mathrm{O} \\
& \mathrm{C}_{7} \mathrm{H}_{5} \mathrm{O}_{2}^{-}+6 \mathrm{NO}_{3}^{-}+7 \mathrm{H}^{+} \rightarrow 7 \mathrm{CO}_{2}+3 \mathrm{~N}_{2}+6 \mathrm{H}_{2} \mathrm{O} \\
& 5 \mathrm{C}_{7} \mathrm{H}_{5} \mathrm{O}_{2}^{-}+6 \cdot 2 \mathrm{NO}_{3}^{-}+11 \cdot 2 \mathrm{H}^{+}+6 \cdot 4 \mathrm{H}_{2} \mathrm{O} \\
& \rightarrow 7\left\langle\mathrm{C}_{4} \mathrm{H}_{7} \mathrm{O}_{3}\right\rangle+7 \mathrm{CO}_{2}+3 \cdot 1 \mathrm{~N}_{2}
\end{aligned}
$$

\begin{tabular}{|c|c|c|}
\hline \multirow[b]{2}{*}{ Growth substrate... } & \multicolumn{2}{|c|}{$\begin{array}{l}\text { Specific activity } \\
{\left[\text { nmol } \text { min }^{-1}\right.} \\
\left.(\mathrm{mg} \text { protein })^{-1}\right]\end{array}$} \\
\hline & Pimelate & Benzoate \\
\hline $\begin{array}{l}\text { Pimelyl-CoA synthetase } \\
\text { (EC 6.2.1.23) }\end{array}$ & 21 & $<0.5$ \\
\hline $\begin{array}{l}\text { Benzoyl-CoA synthetase } \\
(\text { EC 6.2.1.25) }\end{array}$ & $<0.5$ & 18 \\
\hline $\begin{array}{l}\text { Succinyl-CoA: pimelate-CoA transferase } \\
(\text { EC 2.8.3.-) }\end{array}$ & $<0.5$ & 20 \\
\hline $\begin{array}{l}\text { Acetyl-CoA: pimelate-CoA transferase } \\
(\text { EC } 2.8 .3 .-)\end{array}$ & $<0.5$ & $<0.5$ \\
\hline
\end{tabular}

Table 3. Enzymes of pimelate and benzoate activation by cell-free extract of strain LP-1

whereas no activation was measured with acetyl-CoA as CoA donor. Comparison of UV spectra and retention times on HPLC demonstrated that the pimelyl-CoA produced by these reactions was identical with the chemically synthesized one. Alkaline hydrolysis revealed that the thioester was a mono-CoA ester, as indicated by the $1: 1$ stoichiometry of the products pimelate and coenzyme A.

\section{Further degradation of pimelyl-CoA}

Pimelyl-CoA was oxidized by cell-free extracts with an activity of 9-12 $\mathrm{nmol} \mathrm{min}^{-1}$ (mg protein) ${ }^{-1}$ with $\mathrm{K}_{3}\left[\mathrm{Fe}(\mathrm{CN})_{6}\right]$ as artificial electron acceptor, yielding 

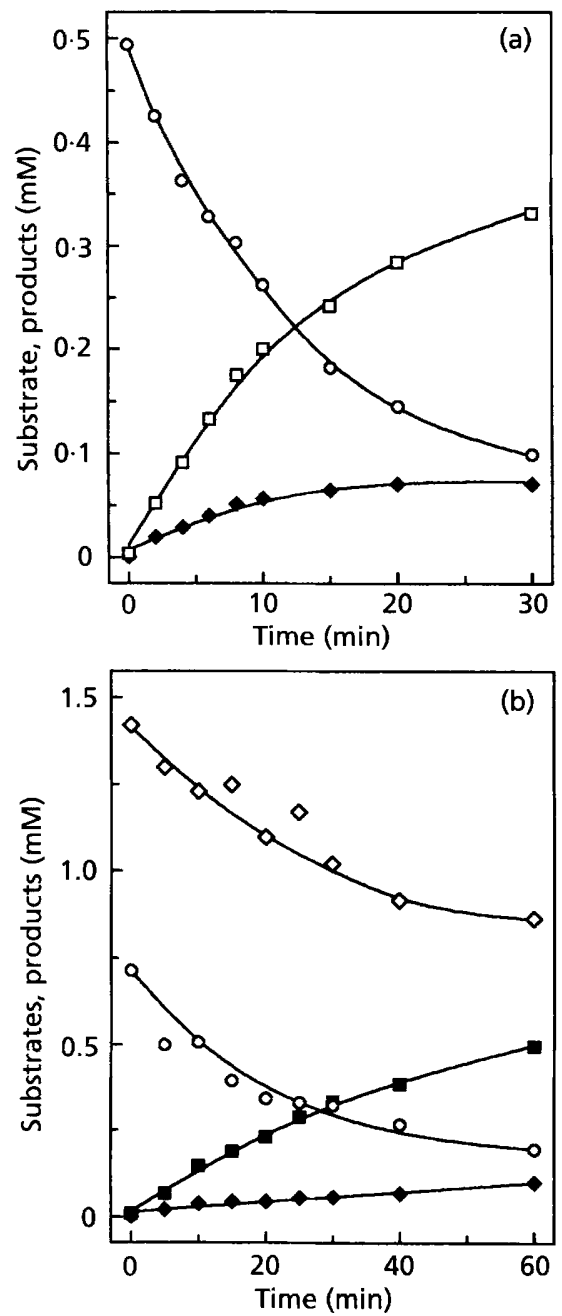

Fig. 3. Activation of (a) pimelate, and (b) benzoate by cell-free extracts of strain LP-1 grown with the respective substrate. $\square$, Pimelyl-CoA; $\mathbf{\square}$, benzoyl-CoA; $\bullet$, acetyl-CoA; O, CoASH; $\diamond$, benzoate.

glutaryl-CoA and acetyl-CoA. The oxidation depended on the presence of cell-free extract of cells grown with pimelate. Since the postulated $\mathrm{C}_{7}$ intermediates were not available, it was not possible to measure single reactions involved in this process. All enzyme activities responsible for further degradation (glutaryl-CoA dehydrogenase, glutaconyl-CoA decarboxylase, and enzymes of fatty acid $\beta$-oxidation) were detected individually in photometric assays, as well as in an assay in which all steps of the entire sequence were coupled. To investigate if these enzyme activities were specific for degradation of pimelate or benzoate, all assays were performed with extracts of cells grown with pimelate, benzoate and also with glucose as a control. Glutaryl-CoA dehydrogenase and glutaconylCoA decarboxylase were present only after growth with pimelate or benzoate, 3-Hydroxyacyl-CoA dehydratase (crotonase), 3-hydroxybutyryl-CoA dehydrogenase, and $\beta$-ketothiolase were constitutive (Table 4). Glutaryl-CoA
Table 4. Specific enzyme activities of cell-free extracts of strain LP-1 grown with either pimelate, benzoate or glucose

\begin{tabular}{|c|c|c|c|}
\hline \multirow[b]{2}{*}{ Growth substrate... } & \multicolumn{3}{|c|}{$\begin{array}{l}\text { Specific activity } \\
{\left[\mu \mathrm{mol} \mathrm{min}^{-1}\right.} \\
\left.(\mathrm{mg} \text { protein })^{-1}\right]\end{array}$} \\
\hline & Pimelate & Benzoate & Glucose \\
\hline $\begin{array}{l}\text { Glutaryl-CoA dehydrogenase } \\
\text { (EC } 1.3 .99 .7)\end{array}$ & $0 \cdot 092$ & 0.031 & $0 \cdot 002$ \\
\hline $\begin{array}{l}\text { Glutaconyl-CoA decarboxylase } \\
\text { (EC } 4.1 .1 .70)\end{array}$ & 0.345 & $0 \cdot 130$ & $0 \cdot 020$ \\
\hline $\begin{array}{l}\text { 3-Hydroxyacyl-CoA } \\
\text { dehydratase } \\
\text { (EC } 4.2 .1 .17 \text { ) }\end{array}$ & $4 \cdot 95$ & $4 \cdot 21$ & $5 \cdot 40$ \\
\hline $\begin{array}{l}\text { 3-Hydroxybutyryl-CoA } \\
\text { dehydrogenase } \\
\text { (EC 1.1.1.157) }\end{array}$ & $0 \cdot 253$ & $0 \cdot 397$ & 0.523 \\
\hline $\begin{array}{l}\beta \text {-Ketothiolase } \\
(\text { EC } 2.3 .1 .16)\end{array}$ & $2 \cdot 74$ & $2 \cdot 57$ & $2 \cdot 95$ \\
\hline
\end{tabular}

degradation by iodoacetamide-treated cell extract resulted in accumulation of acetoacetyl-CoA. The product was identified by its retention time by HPLC and by its specific absorption maximum at $303 \mathrm{~nm}$ after addition of $\mathrm{MgCl}_{2}$. In a similar experiment with pimelyl-CoA, no compound with a specific absorption maximum accumulated that would indicate 3-oxopimelyl-CoA formation.

\section{DISCUSSION}

Four strains of denitrifying bacteria able to grow with pimelate as well as with benzoate as sole carbon and energy source were enriched and isolated. We applied appropriate enrichment conditions to obtain strains capable of growth with both substrates to enable parallel studies on the degradation of these acids. The four new isolates reduced nitrate completely to nitrite before $\mathrm{N}_{2}$ production started. Although nitrite is used as electron acceptor, at high concentrations it acts as an uncoupler of the respiratory chain (van Verseveld et al., 1977). Cultures were therefore grown under nitrate limitation to prevent nitrite intoxication. One strain, LP-1, was further characterized. Cells of this strain were Gram-negative short rods with one polar flagellum, and reacted oxidaseand catalase-positive. Growth was possible only with molecular oxygen or with oxidized nitrogen compounds as electron acceptor. In addition to the enrichment substrates, pimelate and benzoate, many other compounds except $C_{1}$ compounds were degraded in the presence of nitrate. All these characteristics, as well as the capacity to grow at $41{ }^{\circ} \mathrm{C}$, suggest that strain LP-1 is related to the genus Pseudomonas (section II) according to the taxonomy of Palleroni (1984) and should be placed in the family Pseudomonadaceae. Based on rRNA:DNA hybridization studies, de Vos et al. (1989) proposed to limit the genus Pseudomonas to the so-called P. fluorescens rRNA branch, 
which includes the species of section I (Palleroni, 1984) and some other species. This would probably exclude strain LP-1 from the genus Pseudomonas. An exact classification of strain LP-1 would require rRNA:DNA hybridization or $16 \mathrm{~S}$ rRNA studies.

Stoichiometries and electron balances determined for strain LP-1 after growth with pimelate or benzoate demonstrated that both substrates were completely oxidized with nitrate to $\mathrm{CO}_{2}$ and $\mathrm{H}_{2} \mathrm{O}$, according to equations (1) and (3) (see Table 2). The free energy changes are $\Delta G^{\prime \prime}=-3228 \mathrm{~kJ}$ (mol pimelate) ${ }^{-1}$ and $\Delta G^{\prime \prime}=$ $-3031 \mathrm{~kJ}$ (mol benzoate) ${ }^{-1}$ (calculated after Thauer et al., 1977; D'Ans \& Lax, 1983).

Many aromatic acids which are degraded via benzoyl$\mathrm{CoA}$ under anoxic conditions are first activated by an acylCoA synthetase reaction (Geissler et al., 1988; Ziegler et al., 1989; Merkel et al., 1989). Here we show that also the dicarboxylate pimelate is activated with free $\mathrm{CoA}$ in an ATP- and $\mathrm{Mg}^{2+}$-dependent reaction by cell-free extract of pimelate-grown cells of strain LP-1. The results obtained from alkaline hydrolysis of pimelyl-CoA show that only one of the two carboxyl groups is esterified, yielding pimelyl-mono-CoA. The fact that there were also always small amounts of acetyl-CoA produced in the activation assays was presumbably due to the activity of an acetylCoA synthetase using traces of free acetate present in the crude extract. The presence of a constitutive acetyl-CoA synthetase in the denitrifying bacterium Pseudomonas sp. strain KB 740 has already been described (Schennen $e t$ al., 1984). Another effect we always observed was the release of free $\mathrm{CoA}$ resulting from an unspecific thioesterase activity in the cell extract. Formation of pimelyl-CoA by CoA transfer was detected from succinyl-CoA, but not from acetyl-CoA. Considering that our denitrifying strain LP-1 has a respiratory metabolism it is obvious that the organism conserves more metabolic energy by oxidizing acetyl-CoA completely in the citric acid cycle than using it for the activation of the substrate. However, in the case of succinyl-CoA (using 1 ATP equivalent), the ATP yield is higher compared to use of the synthetase reaction (using 2 ATP equivalents). The finding that an activation of pimelate and benzoate was catalysed only by cell-free extracts of cells grown with the appropriate substrate demonstrates that there are two different acyl-CoA synthetases involved, which are substrate-specific and induced by growth with the substrate. Similar results were obtained from experiments with Rhodopseudomonas palustris (Merkel et al., 1989) and with Pseudomonas strain KB 740 (Schennen et al., 1984).

Due to the long C-chain between the CoA thioester and the terminal carboxyl group, the thioester linkage does not polarize the terminal $\mathrm{C}-\mathrm{C}$ bond in a way to allow direct $\omega$-decarboxylation. As long-chain dicarboxylic acids are chemically similar to fatty acids, degradation analogous to $\beta$-oxidation including a dehydrogenation as initial reaction should be preferred. Recently, it has been shown for methanogenic enrichment cultures that longchain dicarboxylic acids of chain lengths $\mathrm{C}_{6}-\mathrm{C}_{10}$ are $\beta$ oxidized rather than decarboxylated (Matthies \& Schink,
1993). In such a pathway of pimelate degradation, 3oxopimelyl-CoA would be produced before thiolytic cleavage to glutaryl-CoA and acetyl-CoA occurs (Blakley, 1978). Further degradation of glutaryl-CoA, which also cannot be directly decarboxylated for the same reasons as mentioned above, has been elucidated for another Pseudomonas-like bacterium (Numa et al., 1964).

In the present study, we demonstrated that pimelyl-CoA was oxidized with ferricyanide by cell-free extracts of pimelate-grown cells of strain LP-1. The first reaction products we found in significant concentrations were glutaryl-CoA and acetyl-CoA. Intermediates between pimelyl-CoA and glutaryl-CoA were not detected. In analogous assays with glutaryl-CoA as substrate and with $\mathrm{K}_{3}\left[\mathrm{Fe}(\mathrm{CN})_{6}\right]$ and $\mathrm{NAD}^{+}$as electron acceptors, the whole reaction sequence yielding acetyl-CoA proceeded without significant accumulation of intermediates as well. Free CoA, the cosubstrate of $\beta$-ketothiolases acting on 3 oxopimelyl-CoA and on acetoacetyl-CoA, was provided through thioesterase reactions. Thus, the initial dehydrogenations appear to be the rate-limiting steps in both pimelyl-CoA and glutaryl-CoA degradation. However, the physiological electron acceptor of 3-hydroxypimelylCoA dehydrogenase is still unknown. Assay mixtures lacking $\mathrm{NAD}^{+}$did not accumulate any other product resembling 3-hydroxypimelyl-CoA. It is possible that ferricyanide also serves as the electron acceptor for this oxidation, in contrast to the 3-hydroxybutyryl-CoA dehydrogenase reaction which we found to be strictly $\mathrm{NAD}^{+}$-dependent.

We could not stop pimelyl-CoA degradation at the level of 3-oxopimelyl-CoA using cell extract preincubated with iodoacetamide. Although 3-oxopimelyl-CoA was not commercially available as reference compound for HPLC analysis, the 3-oxoacyl-CoA compound should be identifiable by a specific absorption maximum at $303 \mathrm{~nm}$ at alkaline $\mathrm{pH}$, analogous to acetoacetyl-CoA (Stern, 1956). In control experiments starting with glutaryl-CoA, acetoacetyl-CoA accumulated in the presence of iodoacetamide-treated cell extract, indicating that this procedure is basically feasible. Thus we conclude that the long-chain thioester is cleaved by a $\beta$-ketothiolase [EC 2.3.1.16] different from that acting on acetoacetylCoA, and that this enzyme is not inhibited by iodoacetamide. An experimental effort to synthesize 3hydroxypimelyl-CoA by condensation of glutaryl-CoA and acetyl-CoA by cell-free extract in the presence of $\mathrm{NADH}$ did not lead to accumulation of the expected product. Possibly the thiolase activity in the direction of condensation is inhibited by free CoA (Suzuki et al., 1987) released from $\mathrm{CoA}$ ester hydrolysis.

All enzyme activities necessary for further conversion of glutaryl-CoA to acetyl-CoA were measured in pimelategrown cells. From these data, we postulate for anaerobic pimelate degradation the pathway depicted in Fig. 4. Recently, Härtel et al. (1993) confirmed that glutaryl-CoA dehydrogenase and glutaconyl-CoA decarboxylase are two activities of one bifunctional enzyme which is involved in anaerobic degradation of benzoyl-CoA. A comparison of the specific enzyme activities measured in 


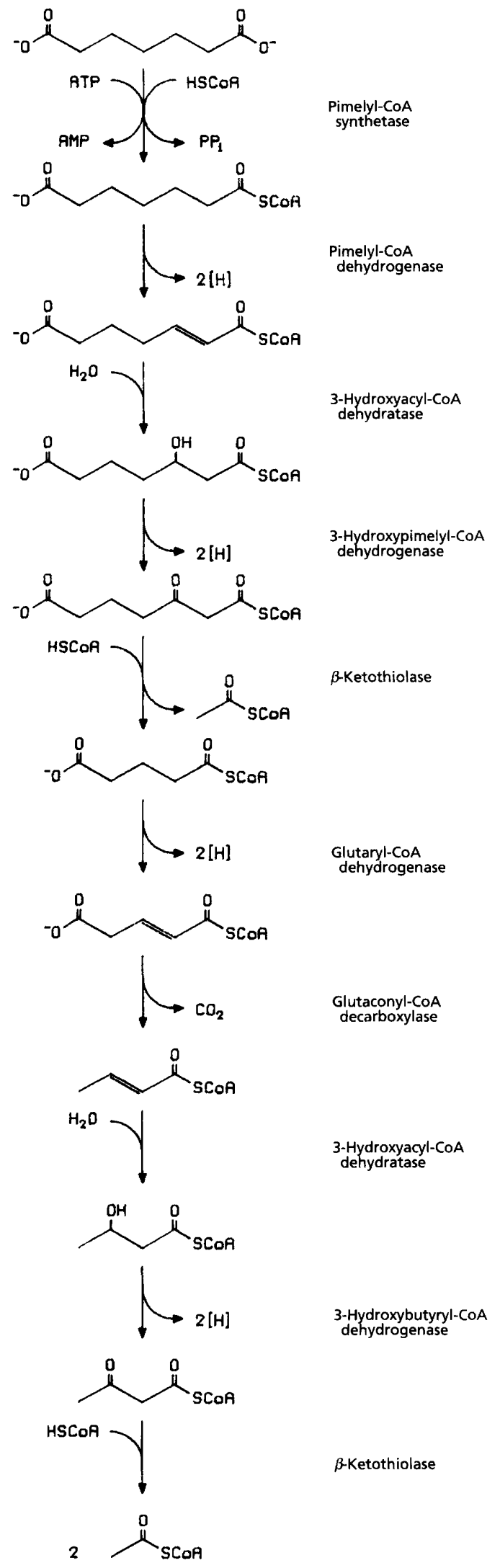

Fig. 4. Proposed pathway of anaerobic degradation of pimelate. cell-free extracts of strain LP-1 after growth with pimelate, benzoate or glucose demonstrates that glutaryl-CoA dehydrogenase and glutaconyl-CoA decarboxylase are induced only after growth with pimelate or benzoate. Hence, we conclude that these enzyme activities are specifically involved in anaerobic degradation of pimelate as well as of benzoate, indicating that the two pathways are connected. The enzymes of classical short-chain $\beta$ oxidation were found to be constitutive as they were present independent of the growth substrate. This finding is not unexpected in an organism able to accumulate poly$\beta$-hydroxybutyrate.

The reactions leading from pimelyl-CoA to glutaryl-CoA were detected in extracts only after growth with pimelate and not with benzoate. This might support the hypothesis that a pimelate derivative other than pimelyl-CoA, such as 3-hydroxypimelyl-CoA (Koch et al., 1993), might be the primary ring cleavage product in anaerobic benzoate degradation.

\section{ACKNOWLEDGEMENTS}

This work was supported by a grant of the Deutsche Forschungsgemeinschaft. We are grateful to Professor Dr W. Buckel, Marburg, FRG, for supplying the enzyme mixture from Acidaminococcus fermentans for assay of glutaconyl-CoA decarboxylase. Special thanks are due to $\operatorname{Dr} C$. Matthies for helpful discussions, and to Dr P. H. Janssen for reading the manuscript.

\section{REFERENCES}

Bartholomew, J. W. (1962). Variables influencing results and the precise definition of steps in gram staining as a means of standardizing the result obtained. Stain Technol 37, 139-155.

Bergmeyer, H. U. (1983). Methods of Enzymatic Analysis, 3rd edn, vols I-III. Weinheim: Verlag Chemie.

Blakley, E. R. (1978). The microbial degradation of cyclohexanecarboxylic acid by a $\beta$-oxidation pathway with simultaneous induction to the utilization of benzoate. Can J Microbiol 24, 847-855.

Blenden, D. C. \& Goldberg, H. S. (1965). Silver impregnation stain for Leptospira and flagella. J Bacteriol 89, 899-900.

Brune, A. \& Schink, B. (1990). Pyrogallol-to-phloroglucinol conversion and other hydroxyl-transfer reactions catalyzed by cell extracts of Pelobacter acidigallici. J Bacteriol 172, 1070-1076.

Buckel, W. (1986). Biotin-dependent decarboxylases as bacterial sodium pumps: purification and reconstitution of glutaconyl-CoA decarboxylase from Acidaminococcus fermentans. Methods Enzymol 125, 547-558.

Cashion, P., Hoder-Franklin, M. A., McCully, J. \& Franklin, M. (1977). A rapid method for the base ratio determination of bacterial DNA. Anal Biochem 81, 461-466.

Chaney, A. L. \& Marbach, E. P. (1962). Modified reagents for the determination of urea and ammonia. Clin Chem 8, 130-132.

Cooper, T. G. (1981). In Biochemische Arbeitsmethoden, pp. 49-51. Berlin: De Gruyter.

D'Ans, J. \& Lax, E. (1983). In Taschenbuch für Chemiker und Physiker, 4th edn, vol. II, Crganische Verbindungen, pp. 1003-1006. Berlin: Springer Verlag.

Dutton, P. L. \& Evans, W. C. (1968). The photometabolism of benzoic acid by Rhodopseudomonas palustris: a new pathway of aromatic ring metabolism. Biochem $J$ 109, 5P. 
Eisenberg, M. A. \& Star, C. (1968). Synthesis of 7-oxo-8-aminopelargonic acid, a biotin vitamer, in cell-free extracts of Escherichia coli biotin auxotrophs. J Bacteriol 96, 1291-1297.

Evans, W. C. \& Fuchs, G. (1988). Anaerobic degradation of a romatic compounds. Annu Rev Microbiol 42, 289-317.

Geissler, J. F., Harwood, C. S. \& Gibson, J. (1988). Purification and properties of benzoate-coenzyme A ligase, a Rbodopseudomonas palustris enzyme involved in the anaerobic degradation of benzoate. J Bacteriol 170, 1709-1714.

Gerhardt, P. (1984). In Manual of Methods of General Bacteriology, pp. 413-420. Washington DC: American Society for Microbiology.

Gottschalk, G. (1986). In Bacterial Metabolism, pp. 43-55. New York: Springer Verlag.

Gregersen, T. (1978). Rapid method for distinction of Gramnegative from Gram-positive bacteria. Eur $J$ Appl Microbiol Biotechnol 5, 123-127.

Guyer, M. \& Hegeman, G. (1969). Evidence for a reductive pathway for the anaerobic metabolism of benzoate. J Bacteriol 99 , 906-907.

Härtel, U., Eckel, E., Koch, J., Fuchs, G., Linder, D. \& Buckel, W. (1993). Purification of glutaryl-CoA dehydrogenase from Pseudomonas sp., an enzyme involved in the anaerobic degradation of benzoate. Arch Microbiol 159, 174-181.

Hasegawa, Y., Hamano, K. \& Obata, H. (1982). Microbial degradation of cycloheptanone. Agric Biol Chem 46, 1139-1143.

Kamen, M. D. \& Horio, T. (1970). Bacterial cytochromes. I. Structural aspects. Annu Rev Biochem 39, 673-700.

Koch, J., Eisenreich, W., Bacher, A. \& Fuchs, G. (1993). Products of enzymatic reduction of benzoyl-CoA, a key intermediate in anaerobic aromatic metabolism. Eur J Biochem 211, 649-661.

Lange, B. \& Vejdelek, Z. J. (1980). Photometrische Analyse. Weinheim: Verlag Chemie.

Lynen, F. \& Ochoa, S. (1953). Enzymes of fatty acid metabolism. Biocbim Biopbys Acta 12, 299-314.

Matthies, C. \& Schink, B. (1993). Anaerobic degradation of longchain dicarboxylic acids by methanogenic enrichment cultures. FEMS Microbiol Lett 111, 177-182.

Merkel, S. M., Eberhard, A. E., Gibson, J. \& Harwood, C. S. (1989).

Involvement of coenzyme A thioesters in anaerobic metabolism of 4-hydroxybenzoate by Rhodopseudomonas palustris. J Bacteriol 171, $1-7$.

Mesbah, M., Premachandran, U. \& Whitman, W. (1989). Precise measurement of the $\mathrm{G}+\mathrm{C}$ content of deoxyribonucleic acid by high performance liquid chromatography. Int J Syst Bacteriol 39, 159-167.

Numa, S., Ishimura, Y., Nakazawa, T., Okazaki, T. \& Hayaishi, O.

(1964). Enzymic studies on the metabolism of glutarate in Pseudomonas. J Biol Chem 239, 3915-3926.

Palleroni, N. J. (1984). Family I. Pseudomonadaceae. In Bergey's Manual of Systematic Bacteriology, vol. 1, pp. 141-219. Edited by N. R. Krieg \& J. G. Holt. Baltimore: Williams \& Wilkins.

Pfennig, N. (1978). Rbodocyclus purpureus gen. nov., sp. nov., a ringshaped, vitamin $B_{12}$-requiring member of the family Rhodospirillaceae. Int J Syst Bacteriol 28, 283-288.

Procházková, L. (1959). Bestimmung der Nitrate im Wasser. Z Anal Chem 167, 254-260.

Rudolphi, A., Tschech, A. \& Fuchs, G. (1991). Anaerobic degradation of cresols by dinitrifying bacteria. Arch Microbiol 155, 238-248.

Schennen, U., Braun, K. \& Knackmuss, H.-J. (1984). Anaerobic degradation of 2-fluorobenzoate by benzoate-degrading, denitrifying bacteria. J Bacteriol 161, 321-325.

Schink, B., Brune, A. \& Schnell, S. (1992). Anaerobic degradation of aromatic compounds. In Microbial Degradation of Natural Products, pp. 218-242. Edited by G. Winkelmann. Weinheim: Verlag Chemie.

Schnell, S. \& Schink, B. (1991). Anaerobic aniline degradation via reductive deamination of 4-aminobenzoyl-CoA in Desulfobacterium anilini. Arch Microbiol 155, 183-190.

Simon, E. J. \& Shemin, D. (1953). The preparation of $S$-succinyl coenzyme A. J Am Chem Soc 75, 2520.

Stams, A. J. M., Kremer, D. R., Nicolay, K., Weenk, G. H. \& Hansen, T. A. (1984). Pathway of propionate fermentation in Desulfobulbus propionicus. Arch Microbiol 139, 167-173.

Stern, J. R. (1956). Optical properties of acetoacetyl- $S$-coenzyme A and its metal chelates. J Biol Chem 221, 33-44.

Suzuki, F., Zahler, W. L. \& Emerich, D. W. (1987). Acetoacetyl-CoA thiolase of Bradyrbizobium japonicum bacteroids: purification and properties. Arch Biocbem Biopbys 254, 272-281.

Tamaoka, J. \& Komagata, K. (1984). Determination of DNA base composition by reversed-phase high-performance liquid chromatography. FEMS Microbiol Lett 25, 125-128.

Thauer, R. K., Jungermann, K. \& Decker, K. (1977). Energy conservation in chemotrophic anaerobic bacteria. Bacteriol Rev 41, $100-180$.

Tschech, A. \& Fuchs, G. (1987). Anaerobic degradation of phenol by pure cultures of newly isolated denitrifying pseudomonads. Arch Microbiol 148, 213-217.

Tschech, A. \& Pfennig, N. (1984). Growth yield increase linked to caffeate reduction in Acetobacterium woodii. Arcb Microbiol 137, 163-167.

van Versefeld,, H. W., Meijer, E. M. \& Stouthamer, A. H. (1977). Energy conservation during nitrate respiration in Paracoccus denitrificans. Arch Microbiol 122, 17-23.

de Vos, P., van Landschoot, A., Segers, P., Tytgat, R., Gillis, M., Bauwens, M., Rossau, R., Goor, M., Pot, B., Kersters, K., Lizzaraga, P. \& de Ley, J. (1989). Genotypic relationships and taxonomic localization of unclassified Pseudomonas and Pseudomonas-like strains by deoxyribonucleic acid:ribosomal ribonucleic acid hybridizations. Int J Syst Bacteriol 39, 35-49.

Weimer, P. J. \& Zeikus, G. (1977). Fermentation of cellulose and cellobiose by Clostridium thermocellum in the absence and presence of Methanobacterium thermoautotrophicum. Appl Environ Microbiol 33, 289-297.

Widdel, F. \& Pfennig, N. (1981). Studies on dissimilatory sulfatereducing bacteria that decompose fatty acids. I. Isolation of new sulfate-reducing bacteria enriched with acetate from saline environments. Description of Desulfobacter postgatei gen. nov., sp. nov. Arch Microbiol 129, 395-400.

Widdel, F., Kohring, G. W. \& Mayer, F. (1983). Studies on dissimilatory sulfate-reducing bacteria that decompose fatty acids. III. Characterization of the filamentous gliding Desulfonema limicola gen. nov., sp. nov., and Desulfonema magnum sp. nov. Arch Microbiol 134, 286-294.

Ziegler, K., Buder, R., Winter, J. \& Fuchs, G. (1989). Activation of aromatic acids and aerobic 2-aminobenzoate metabolism in a denitrifying Pseudomonas strain. Arcb Microbiol 151, 171-176.

Received 14 June 1993; revised 9 August 1993; accepted 6 September 1993. 